\title{
Historical and contemporary waterscapes of North Australia - Indigenous attitudes to dams and water diversions
}

\section{Sue Jackson ${ }^{\text {a }}$}

and Marcus Barber ${ }^{b}$

\begin{abstract}
Indigenous engagements with water are dynamic and contextually contingent, and contemporary attitudes and environmental valuations are shaped by diverse pre-existing water histories. Geographical variation intersects and interacts with such histories to influence the moral position taken by individuals and groups and their negotiating position as they engage in public debates or decisions about water diversion, management, and use, as well as the tradeoffs and risks of associated negative impacts. This paper draws together Indigenous historical and contemporary perspectives regarding the diversion, damming and manipulation of water sources from four tropical watersheds that span Australia's remote north - the Harding and Ord Rivers in Western Australia, the Roper River in the Northern Territory, and the Gilbert River in North Queensland. Conceptually, the paper brings together the literatures of Indigenous water values and the political ecology of water resources. The analysis deploys the waterscape concept that has emerged from geography and history to characterise the key features of Indigenous peoples' dynamic relationships to water and to link water and social power relations in these watersheds over time. The cases support the proposition that Indigenous people are often concerned about industrial-scale water diversion and damming. Yet our regional studies also undercut the notion that such concerns emerge from an Indigenous culture that passively responds to the prevailing hydrology, or the idea popular in settler Australia that these hydraulic environments are themselves unaffected by past human action. Indigenous attitudes to diversion and damming are informed by previous experiences of water manipulation, which include the social relations that shaped these practices, at times with demonstrably pre-colonial origins, as well as by contemporary perspectives on the tradeoffs
\end{abstract}

\footnotetext{
${ }^{a}$ Professor, Australian Rivers Institute, Griffith University and Honorary Fellow, School of Geography, The University of Melbourne.

${ }^{\mathrm{b}}$ Senior Research Scientist, CSIRO
} 
Jackson, S. and M. Barber 2016. Historical and contemporary waterscapes of North Australia: Indigenous attitudes to dams and water diversions. Water History 8(4): 385-404 http://hdl.handle.net/10072/204548

between development, sustainable local livelihoods, and environmental and cultural impact. Our analysis of the Australian context informs ongoing international debates about large scale irrigated agriculture, aquaculture, mining, and other water-intensive development in regions occupied by Indigenous peoples and experiencing high and increasing water variability.

Keywords: Indigenous water rights, native title, water values, environmental history, water cultures

\section{Acknowledgements}

The authors would like to acknowledge the Indigenous participants of the Roper, Pilbara, and Gilbert River studies. Funding for the projects upon which this work is based was obtained from a range of sources: CSIRO, Griffith University, Rio Tinto Iron Ore, the Office of Northern Australia, the North Australia Water Futures Assessment and the Australian Research Council (project FT130101145). The views expressed herein are those of the authors and are not necessarily those of any funding body.

\section{Author Biographies}

Sue Jackson is a human geographer at the Australian Rivers Institute, Griffith University, Brisbane, Australia. She has research interests in systems of resource governance, including customary Indigenous resource rights, and Indigenous capacity building for improved participation in natural resource management and planning, as well as the social and cultural values associated with water.

Marcus Barber is an anthropologist with the Adaptive Social and Economic Systems programme of the Commonwealth Scientific and Industrial Research Organization (CSIRO), based in Brisbane, Australia. His research specialization is marine, water, and environmental issues as they relate to Indigenous Australians. 
Jackson, S. and M. Barber 2016. Historical and contemporary waterscapes of North Australia: Indigenous attitudes to dams and water diversions. Water History 8(4): 385-404 http://hdl.handle.net/10072/204548

\section{Introduction}

The concept of 'waterscape' (Loftus 2007; Budds \& Hinojosa 2012; Hundley 1987), and associated concepts such as 'waterworld' (Orlove and Caton 2010) and the 'hydro-social cycle'(Swyngedouw 2004; Boelens 2013; Palmer 2015), have been productively used in recent decades by researchers focused on deepening understanding of the relations between people and water (Strang 2004), and on the political nature of resource contests that can emerge from such relations. Scholarship by geographers, anthropologists and historians challenges conventional conceptualisations of water as a material and politically-neutral resource that is objectified and governed by the state and other actors. Instead, it highlights how research can 'recognise water as a form of hybrid socio-nature, at once natural and socially produced, and which both embodies and reproduces forms of social power' (Perreault, Wraight, and Perreault 2012, 489; see also Swyngedouw 1999; Loftus and Lumsden 2008).

According to this perspective, waterscapes are co-constituted by, and bear the imprint of, human labour action and social struggle. Uneven power relations are manifest in such attributes as water rights, access, use, flow and quality and 'in turn, these characteristics serve to shape, reinforce, and reproduce those same power geometries' (Perreault et al. 2012, p.489). Competing social constructions of nature are deployed by differentially situated groups to promote their interests and their preferred ways of managing nature, including water (Budds 2008), in what Boelens refers to as 'schemes of water-based belonging' (2013, p.234).

Concepts that emphasize the combined social and natural elements of water are particularly constructive in considering dams and other forms of river regulation. Swyngedouw's work on the role of dam building and ideologies associated with Spanish nationalism (1999) exemplifies how water-society interactions can be considered in terms of historical trajectory, social power, and material flows. Understanding dams as part of a wider historical and geographic waterscape enables consideration of 'water-related artefacts, institutions, and imaginaries that embody and express power' (Budds \& Hinojosa 2012, p.125).

In what follows, we provide historical and geographic context to the role of dams and diversions in Indigenous waterscapes in key northern Australian watersheds. Using four waterscapes, we examine the social struggles over dams and diversions in terms of their relations to Indigenous water use practices, cultural and metaphysical realities, and environmental impacts. The empirical material is presented thematically, but also reflects 
Jackson, S. and M. Barber 2016. Historical and contemporary waterscapes of North Australia: Indigenous attitudes to dams and water diversions. Water History 8(4): 385-404 http://hdl.handle.net/10072/204548

chronological, geographic and procedural changes in settler colonial relations that continue to shape Indigenous perspectives on damming and diverting rivers. We highlight the degree to which Indigenous people have been able to assert their own development choices within each waterscape i.e. how the power geometries affect Indigenous relations with and access to water, as well as their capacity to undertake culturally preferred modes of management. We show that Indigenous engagements with water are dynamic and contextually contingent, and contemporary attitudes and environmental valuations are shaped by diverse pre-existing water histories. We challenge the notion that environmental attitudes emerge from an Indigenous culture that passively responds to the prevailing hydrology, or the idea popular in settler Australia that these hydraulic environments are themselves unaffected by past human action. Indigenous attitudes to diversion and damming are informed by previous experiences of water manipulation, which include the social relations that shaped these practices, at times with demonstrably pre-colonial origins, as well as by contemporary perspectives on the tradeoffs between development, sustainable local livelihoods, and environmental and cultural impact. Before considering the cases in detail, we will first review some key aspects of the wider context of Indigenous people and water in Northern Australia.

\section{Indigenous Australians and water}

For tens of thousands of years, Indigenous occupation of the Australian continent depended on detailed knowledge of water distribution, landscape modification and the use of technology to harvest water and aquatic resources (Bandler 1995). The resource management repertoire of Indigenous societies involved careful maintenance of water sources, utilization of wells, and the construction of small-scale water diversions, impoundments or dams (Lourandos 1980). Early colonial and explorers accounts noted 'black-fellows' tanks' (Abbott 1884) and other human augmented or created storages and water manipulations, while waterways were sometimes extensively engineered to create channel and trap systems for fish and eel production (Humphries 2007; Gammage 2011). Despite this activity, the prevailing colonial attitude was that Indigenous Australians were nomadic hunter-gatherers and did not modify or manage the environment. Hydrological manipulation and modification therefore has remained an unrecognized Indigenous management practice (Gammage 2011; Barber \& Jackson 2015) and this issue forms one motivation for exploring the ideas presented in this paper.

Rich religious and symbolic traditions relating to water complement its material uses for Indigenous people (Merlan 1987; Bradley 2010). Water itself is understood as an integral part 
Jackson, S. and M. Barber 2016. Historical and contemporary waterscapes of North Australia: Indigenous attitudes to dams and water diversions. Water History 8(4): 385-404 http://hdl.handle.net/10072/204548

of the world created by the ancestral beings during what is colloquially known as the Dreaming, and those beings are still present in current land and waterscapes (Williams 1986; Barber 2005; Toussaint et al. 2005). This means that Indigenous people consider the land and waterscapes as living entities that are responsive to human actions and human behavior (Rose 1996; Barber \& Jackson 2011b). The ancestral beings also created the cultural institutions governing Indigenous peoples' systems of rights and interests - rights and responsibilities in relation to places under Indigenous law that arise from what Langton refers to as 'wide mythogeographical bodies of knowledge' (2002, p.45). Possession of knowledge of the environment, its natural features and vitally, its spiritual dimensions, is a prerequisite to exercising rights to land and water. The crucial sustaining role of culture and country, and of the laws and practices that are associated with them, also place a heavy obligation on its current custodians to protect and pass on as much knowledge as they can to subsequent generations. Rapid loss of knowledge is a source of concern and motivation to many Indigenous elders and to those belonging to community-based organisations that undertake environmental management activities.

\section{$\underline{\text { North Australia }}$}

With 55 watersheds covering an area of more than 1.3 million $\mathrm{km}^{2}$, north Australia comprises $15 \%$ of Australia's landmass yet its rivers account for about $65 \%$ of the country's runoff (see Figure 1). The tropical climate of alternating wet and dry seasons means that surface water availability is highly seasonal. Grazing is the most extensive land use in all catchments whilst resurgence in mining activities is underway (Webster et al. 2009). Water is extracted for agriculture, albeit at relatively low rates. Speculation about the potential to harness this seasonally plentiful resource has been constant over a recent decadal drought as the volume of water stored in major reservoirs in southern Australian declined (Blanch 2008). In the decade since, Federal and northern state governments have magnified the focus on potentially valuable northern water resources, releasing a National Plan for Water Security in 2007 and a North Australia Development White Paper in 2015. These plans and policies, inter alia, are examining the potential for further land and water development, particularly irrigated agricultural development reliant on surface water dams and groundwater exploitation. Despite past development and the pressure to intensify it, Australia's north contains one of the world's highest concentrations of free-flowing systems (Australian Tropical Rivers Group 2004). 


\section{Figure 1 (Map of north Australia)}

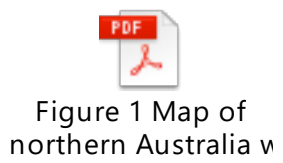

Northern Australia's rivers and wetlands are environments of vital importance to the numerous Indigenous language groups who are closely connected to these landscapes via customary tenure, pre-historical, historical, and/or contemporary residence, the continued use of aquatic resources, cosmological beliefs and a body of environmental knowledge accumulated over hundreds of generations. In light of the region's climatic variability, permanent sources (rivers, creeks, springs, etc.) are of major religious and material significance. Underground waters are also significant for their part in sustaining life and feature in Indigenous ritual knowledge (Cooper \& Jackson 2008). Riverine corridors and other water sources that support larger numbers of people contain higher concentrations of culturally-significant landscape features including places with personal, family or clan group associations, such as campsites, fishing and resource-gathering sites, birth and burial locations, and sacred sites (Barber \& Jackson 2011b; Barber 2005).

\section{Water and colonization}

Corresponding to their importance to Indigenous people, key water sources are also places where historical and contemporary development activity is concentrated. The history of nonIndigenous settlement of northern Australia involved the progressive alienation of land for pastoral, mining, residential and commercial/industrial purposes. The strategic appropriation by initial settlers led to the establishment of permanent population centres, and water sources were often sites of major conflict as well as subtler forms of exclusion and appropriation (Barber \& Jackson 2014; Wegner 1993). In what has been termed 'the battle for the waterholes', animals introduced upon colonization - buffalo, cattle, and horses - all had a widespread negative effect on traditional life-ways (McGrath 1987). Enormous ecological pressure was created as waterholes became stock watering points and the resulting social impact included severe anxiety from disturbance to sacred sites, and conflict over hunting of introduced animals which had often displaced native game. 
Jackson, S. and M. Barber 2016. Historical and contemporary waterscapes of North Australia: Indigenous attitudes to dams and water diversions. Water History 8(4): 385-404 http://hdl.handle.net/10072/204548

Following the early colonial violence against Indigenous people, a coercive form of interdependence emerged in the pastoral industry that was the focus of development activity. Indigenous exclusion from the benefits of resources relied on permanent non-Indigenous presence, which in turn relied on the exploitation of a 'pacified' Indigenous labour force, at least until a combination of wage increases, mechanization, and land use changes in the 1960s rendered such a requirement for labour redundant (Barber \& Jackson 2015). During the period in which their labour was required, Indigenous people enjoyed continued, though conditional, access to water sources for customary purposes (McGrath 1987, Barber and Jackson 2014).

More recently, land restitution schemes and the recognition of native title have returned considerable amounts of territory to Indigenous control. Almost a third of northern Australia's 300,000 inhabitants are Indigenous and, as a result of post-colonial land claims and recognition of native title, they now own approximately a quarter of the region's land mass (Jackson \& Altman 2009). However, pastoral leases remain the dominant form of land tenure. Mining has provided some significant economic benefits to Indigenous people, but also pose major challenges for Indigenous communities (Langton \& Mazel 2008). The impacts on waterscapes from mining development have included water usage and water quality issues, but also (as is reflected in the case study here) impacts from the large scale extraction and relocation of water.

In contrast to pastoralism, the relatively low rates of farming of land in north and central Australia where Indigenous land ownership is concentrated has meant that Indigenous involvement in agriculture has been restricted to this point. Although the majority of the plans and promises to develop agriculture across the north have not been realized, they have influenced the land use policy and development politics of the last century, being frequently enrolled in the service of 'white Australia's attempts to possess the landscapes of the north' (Head 2000, p.174). Lack of Indigenous participation in agriculture increases the risk to local Indigenous populations of water resource development proposals that have sophisticated, industrial-scale agricultural irrigation as a primary objective - Indigenous people are vulnerable to the potential impacts without necessarily being well positioned to enjoy the (largely economic) benefits accruing from such development (Head 2000; McLean 2012; Stoeckl et al. 2013; Barber 2005).

\section{The case studies of Indigenous waterscapes}

Origins of the case studies 
Jackson, S. and M. Barber 2016. Historical and contemporary waterscapes of North Australia: Indigenous attitudes to dams and water diversions. Water History 8(4): 385-404 http://hdl.handle.net/10072/204548

During the period 2010 - 2015, the authors conducted a series of regional studies of the significance of water to Indigenous peoples and of matters relating to water governance (encompassing values, knowledge, institutions such as law, norms and practices, ethics and management systems) in key locations in Queensland, the Northern Territory, and Western Australia (Barber \& Jackson 2011a; Barber \& Jackson 2012; Jackson \& Barber 2013; Barber \& Jackson 2015; Barber 2013; Barber \& Jackson 2014) (see Figure 1). This research was motivated by an awareness that future water use is projected to increase in the regions concerned, and that governments, Indigenous organisations, water resource developers and the wider community ought to be well informed about Indigenous water values, rights and interests so as to proactively manage current and future impacts. The title of each waterscape example highlights a particular characteristic of that instance of damming and diversion.

An autonomous Indigenous waterscape - adapting indigenous weir building in the Roper River, Northern Territory

In general, there is relatively little archaeological and historical evidence for Indigenous manipulation of water flows in north Australia. However, an instance of pre-colonial Indigenous damming and diversion in the Roper River of the Northern Territory was fully investigated for the first time by the authors (Barber \& Jackson 2015). It represents a distinctive social, ecological, and spatial feature of the local waterscape with the potential for long-term effects on the catchment environment.

First documented by pastoralists at Elsey Station early in the 20th century (Gunn 1908), these temporary weir structures were built in the shallow, braided sections of the Roper River in the mid to late dry season (see Figure 2). Constructed of paperbark and palm tree trunks, they encouraged water retention in swamps and billabongs (isolated branches of a river) lying upstream from the weir, increasing the size and duration of available wetland habitat for key food species including fish, birds, reptiles and aquatic plants (Gunn 1908). Based on its effectiveness for a relatively modest outlay of time, energy and materials, it seems quite possible that the practice is very old and may well have been practiced in other appropriate locations in the dry tropics.

Access to both water supplies and Indigenous labour was critical to the success of settler colonial pastoralism. At Elsey Station, it became clear that weirs built by Indigenous people for Indigenous purposes had an added benefit, directing water to areas from which cattle were easily able to drink without getting bogged. The practice intentionally minimized stock losses, 
Jackson, S. and M. Barber 2016. Historical and contemporary waterscapes of North Australia: Indigenous attitudes to dams and water diversions. Water History 8(4): 385-404 http://hdl.handle.net/10072/204548

the degradation of water quality due to the presence of animal carcasses, and the need to assign Indigenous stockmen to the task of rescuing stranded animals. Therefore, weir construction adjacent to what was known as Red Lily Lagoon was encouraged by non-Indigenous station owners and managers in the 1920s and 1930s to the point where a downstream station owner complained. The matter ended up in court in 1946, and so the earliest consideration of Indigenous natural resource rights in an Australian court located thus far actually concerned a practice of water damming and diversion.

\section{Insert Figure 2 here -}

Caption: 'Destroying the dam, 16/10/1938'. Photograph by Constable James Mannion. Courtesy of the Northern Territory Police Museum.

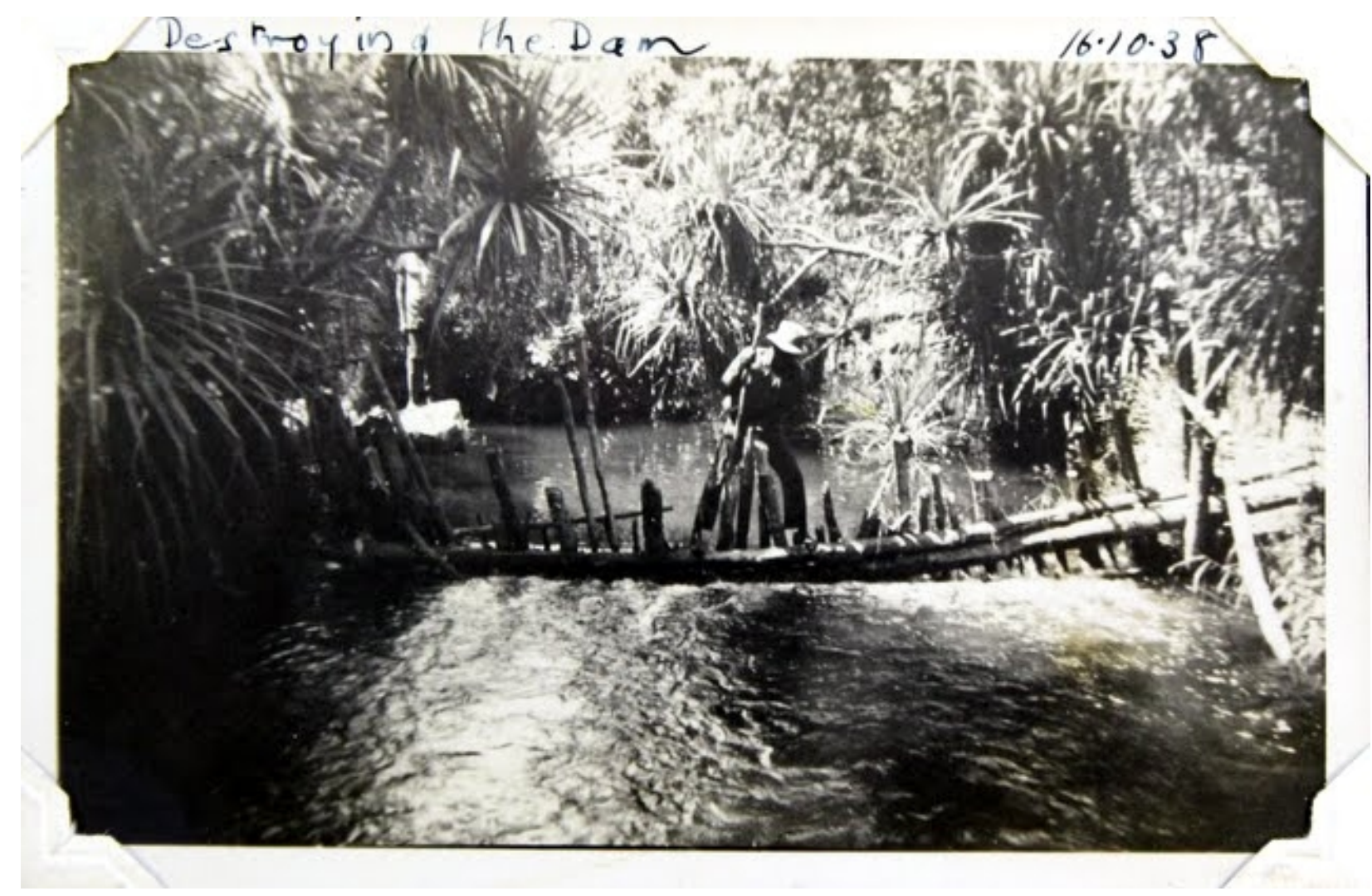

The practice was known locally as “the 'blackfellows' dam” by colonial administrators and engineers and initially treated as an expression of 'blacks' water rights' by the pastoral owner 
Jackson, S. and M. Barber 2016. Historical and contemporary waterscapes of North Australia: Indigenous attitudes to dams and water diversions. Water History 8(4): 385-404 http://hdl.handle.net/10072/204548

of Elsey Station. For their part, government staff who investigated the matter prior to the case were able to characterize the practice positively, seeing a potential future role for dams in rice cultivation. One government engineer saw its potential application to the 'scientific storing of water for stock' and even described the area as 'a Water Conservation and Irrigation Engineer's Dream' (Correspondence from Assistant Engineer Whitlock to Chief Engineer, Department of the Interior, 27 September 1938, National Archives of Australia File F1 1946/406. Darwin.). However, rather than a matter concerning 'black's water rights', the case was legally classified and heard as a dispute between the owners of Elsey Station and the downstream station owner over riparian rights. Consequently, the judge found in favour of the downstream station, ordered Elsey Station to pay damages, and banned further weir building (Barber and Jackson 2012a).

In contemporary times, what is of most interest is the detail with which the Indigenous weir building practice was documented, rather than the basis of the legal decision. Indigenous people interviewed at the time asserted the ancestry of the practice and that it was intended to stop the water going the 'wrong way' - an active intervention in water flows that had deep pre-colonial origins. Demonstrating both the autonomy of Indigenous waterscapes and the constraints of settler colonialism, Indigenous people ceased constructing the weir where the court had formally banned it, but continued constructing similar weirs and barrages on adjacent properties for some decades afterwards to provide water to grow fodder for cattle - Indigenous interventions in local waterscapes went on. The weir-building practice was re-instituted again in 2010 as an attempt to mitigate damage from erosion during an era in which Indigenous land management is a prevalent and important form of Indigenous activity on the land (Altman \& Kerins 2012). This indicates that, since 1900, there have been at least four different purposes for Indigenous damming and diversion on the Roper River - subsistence, drinking water for cattle, growing fodder, and environmental management through erosion mitigation. Although variations in geographic conditions elsewhere meant that this kind of weir building activity was not ubiquitous, the Roper waterscape demonstrates the principle that the damming, diversion and manipulation undertaken by Indigenous inhabitants in a locally autonomous fashion was entirely consistent with other Indigenous waterscapes of north Australia.

Indigenous responses to a mining waterscape - the imposition of the Harding dam, Pilbara, Western Australia 
Jackson, S. and M. Barber 2016. Historical and contemporary waterscapes of North Australia: Indigenous attitudes to dams and water diversions. Water History 8(4): 385-404 http://hdl.handle.net/10072/204548

We now turn to a waterscape in which Indigenous peoples experienced the imposition of a dam and associated infrastructure ostensibly to support population growth associated with the mining sector in the Pilbara region of Western Australia. Indigenous people in this area were affected by colonial appropriation in similar ways to the people of the Roper River region, with a negative initial impact followed by absorption of their labour power into the pastoral industry. Ongoing participation in pastoralism enabled them to maintain links and connections with traditional country and cultural water sites for considerably longer than Indigenous people further south in the state (Rumley \& Barber 2003). The rich mining resources brought prospectors to the region as early as the 1870 s, but it was in the 1960s that large scale mining of iron ore began to rapidly transform the economy and demography and heavily impact upon Indigenous culture and land and waterscapes (Rumley and Barber 2003). Much significant mining development in the Pilbara predated the enactment of the Aboriginal Heritage Act (1972) by the Western Australian government that made it an offence to damage or destroy an Aboriginal site, whether registered or not. The densest concentrations of living areas and sites associated with Dreamtime ancestral pathways were predictably to be found in the vicinity of rivers and creeks, pools and soaks (small area of land that retains water) (Palmer 1977; Daniel 1990).

In 1983, a little over a decade following the enactment of this legislation, a local waterscape of major importance to Indigenous people, Lockyer's Gorge, was impacted by a dam (Barber and Jackson 2011a). The situation arose because rapid industrialization of the Pilbara had occurred, relying on agreements between mining companies and the state government such as the one made in the early 1960s for the state's Public Works Department (PWD) to provide water facilities (Rumley and Barber 2003). An initial PWD proposal in the early 1970s to dam the Fortescue River was abandoned following strong Pilbara-wide opposition from Indigenous communities. A subsequent proposal to dam the Harding River emerged, and a heritage application was made by Pilbara Indigenous groups to stop dam construction. This act represented the first time Pilbara Indigenous people had officially registered their objections to the loss of their land and destruction of cultural sites (Rumley and Barber 2003). A recommendation from the state government heritage agency had concluded that:

'If a dam is to be built at [at Cooya Pooya], additional research would be required to safeguard the interests of an as yet politically voiceless minority, and some very real 
Jackson, S. and M. Barber 2016. Historical and contemporary waterscapes of North Australia: Indigenous attitudes to dams and water diversions. Water History 8(4): 385-404 http://hdl.handle.net/10072/204548

negotiations would have to take place with Aboriginal people' (Palmer et al. 1978, p.13).

However, the official heritage objection was ultimately rejected by the state government and the dam approved without further consultation (Olive 2007). Construction involved the destruction and reconstruction of rock formations for the dam wall and the subsequent inundation and interruption to the natural flow regime. It represented the first major modern water development in the region, flooding an area that was very culturally and ecologically important to Indigenous people (Palmer 1977). This, combined with the failure of water resource developers to consult Indigenous people, only increased the anger amongst Indigenous people when the consequences of the dam for local and regional waterscapes became clear:

‘... those trees have gone! They insulted this ground! Finish! They’ve broken it up! Finish! This one here, they break this one too! That's the place we used to camp here. Everything's busted up! We used to walk down there up the river. Can't do nothing now! Finished! They put water in it. Bad! There was a sacred tree there that is not allowed to be cut down. I don't know if he is there now. The 'Tree in the Moon', is he still standing? Nothing, he's under the water. They cut that down. They're not allowed to do that! God put that tree there! Not supposed to do that!' (Lilla Snowball in Rijavec 1993).

Affected Indigenous groups only received modest compensation (Rumley and Barber 2003). The story of the Harding Dam has appeared in a range of publications since it was built, 30 years ago, demonstrating that the issue remains significant. Indigenous participants in a 2004 study said that the "country is all dying now because there is no water even in the wet season (Rumley and Barber 2003:41). The flooding of the rainmaking site Bunggarliyarra and the 'Tree in the moon' (Nganirrina) site have remained of particular concern, but the loss of an important camping place in the flooded valley and the drying-up of the Ngurin River downstream of the dam also had a significant impact on subsistence fishing and hunting:

'They took all the trees, all the beautiful trees, the paperbarks, they took it all and even a church mob, us mob, we used to go there and camp out along there. People had knowledge of their land. Go for camp-outs. Some people were baptised there, a special place, a lovely ceremonial spot. My grandfather went through the law somewhere there. The white men just wanted to do their own thing. Not listen to us mob talking. There's 
Jackson, S. and M. Barber 2016. Historical and contemporary waterscapes of North Australia: Indigenous attitudes to dams and water diversions. Water History 8(4): 385-404 http://hdl.handle.net/10072/204548

also the problem of Ieramugadu (Roebourne) for that's where they used to fish and swim and now it gets dry' (Tootsie Daniels in Olive 2007, p.20).

The shallow topography of the Harding valley and the high rates of evaporation have limited the water storage capacity of the dam and, as a result, securing the water supply for the major town of Karratha has ultimately required augmentation with groundwater extracted from a nearby bore-field in another area of great ecological and cultural importance, Jirndawurrina (Millstream). These technical deficiencies in what transpired to be a suboptimal water supply from the dam have compounded the anger felt by traditional owners at the impacts of inappropriate water resource development to support mining.

Indigenous responses to an agricultural waterscape: Ord River dams, Kimberley, Western Australia

A similar disregard of Indigenous waterscapes and the need for consultation was evident during the process of project planning for and implementation of the Ord River Irrigation Scheme in the Kimberley, north-west of the Pilbara in Western Australia (Barber and Rumley 2003). The Scheme was built in stages commencing in the 1960s, although proposals to augment the pastoral industry with a permanent water supply date back over a century. The two dams, the Diversion dam and Main dam, were constructed in 1963 and 1972 respectively, facilitating the irrigation of over $117 \mathrm{~km}^{2}$ of land under the ownership of non-Indigenous farmers. Australia's largest artificial lake by volume, Lake Argyle, was created in the process. Channels were created and the adjacent land was laser-levelled in order to maximize the effectiveness of distributing water across the terrain.

The original evaluation of the potential benefits and impacts of agriculture and its hydraulic infrastructure was typical of the modernist era so comprehensively critiqued by bodies such as the World Commission on Dams (World Commission on Dams 2000). For example, no costbenefit analysis was undertaken (Davidson 1972). The dams resulted in dramatic alterations to the environment of the lower Ord River. Dry season river flows were intermittent whereas now they are continuous and substantially higher. Average dry season flows have increased almost fivefold and the dam structures have significantly reduced the extensive inundation of adjacent floodplains that occurred every wet season. Riparian areas now comprise floral species from other ecological niches, arrayed along the banks of the river in a composition and density previously unseen (Barber and Rumley 2003). 
Jackson, S. and M. Barber 2016. Historical and contemporary waterscapes of North Australia: Indigenous attitudes to dams and water diversions. Water History 8(4): 385-404 http://hdl.handle.net/10072/204548

Initial experimentation with cotton and a wide array of other crops failed due to pest problems. Recently there have been some successes in horticulture and forestry that have increased economic returns from the farmers, but at vastly less than the level required to recoup the cost of state investment in the project (Head 1999; Gosford 2014).

The development fundamentally altered the existing Indigenous waterscape. Floodwaters displaced Indigenous people and cultural sites, graves and hunting grounds were inundated. Access to the river has also become more difficult as land was subdivided and vegetation closed in on the river banks. Barber and Rumley (2003) describe the enduring effects:

'... the sense of loss of country was/is very painful to Aboriginal people... The loss of land to artificially-created lakes and farmland disrupted Aboriginal connections to land in a spiritual, cultural and material sense. Not only were sites inundated, but Aboriginal access was cut off, thus increasing resentment about restrictions on traditional activities. Hunting, fishing and gathering become problematic with a consequent impact on diet and health' (p. 31).

Further, with the natural drainage disrupted, billabongs created by the Dreamings have disappeared. Regular water flow, an absence of annual flushing and weed infestations have all produced assemblages that bewilder and distress the Indigenous people. Barber and Rumley (2003) argue that the Ord development modified the environment

'... in such a fashion that elements are now disjuncted from the historic past and the myths which are an important component of the traditional owners' cultural heritage. In doing so, the (Ord dam) process and subsequent land use has removed the certainty provided to the traditional owners by the Dreaming' (p. 24).

In effect, the development represents rupture in the metaphysics of the pre-colonial waterscape. These new environments are now typically described as 'closed up' by Indigenous people, who are further perturbed because they do not possess the detailed knowledge that was exercised and relied upon in the daily life of the pre-dam waterscape. Where the environment was generally predictable and ordered, the post-dam environments are disordered and illegible. Ephram Kennedy, a traditional owner describes the effect on his community's ability to rely on age-old practices and generative socio-ecological relationships: 
Jackson, S. and M. Barber 2016. Historical and contemporary waterscapes of North Australia: Indigenous attitudes to dams and water diversions. Water History 8(4): 385-404 http://hdl.handle.net/10072/204548

'The old people say 'we don't know this place anymore... the flooding and all the water has changed the river'. They used to catch fish with their hands. You can't do that anymore' (Barber \& Kennedy 2007, p.70).

There have been limited benefits to Indigenous people from the project to counteract the tangible and intangible costs. McLean (2012), noted that the process that applied to the first stage of the Ord project

did not include recognition of Indigenous custodianship of land, did not encourage participation of Indigenous people in planning over natural resources, or, as to be expected without the previous two conditions, was not premised on fair distribution of the benefits of development (p. 344).

According to Barber and Kennedy (2007), Indigenous people were initially able to work as labourers on the project, but jobs for Indigenous people eventually declined with mechanisation.

Developments in native title law in the 1990s enabled a pathway for discussions about remediation of impacts arising from the first stage of development and where possible restitution of access and other rights. By the time that proposals for an expansion of the irrigation system were on the table local Indigenous rights and interests in the lands, waters and natural resources of Ord River region were being adjudicated in the courts. Historic native title legislation introduced in 1993 following a High Court decision in 1992 (Brennan et al. 2015) meant that any expansion of the irrigation district would have to proceed in a very different manner to that carried out forty years ago. At the least it would require that proponents consult and negotiate with the Indigenous owners in accordance with the Native Title Act (1993) and that sites of significance would be protected as per current heritage legislation. Local Indigenous representative organisations prepared a social impact study of the effects of the first stage of the Ord Scheme to inform negotiations over the proposals for the next stage (Barber \& Kennedy 2007). Traditional owner, Ephram Kennedy outlines what

That report talks about the damage to the river from the dam and the impacts on Miriuwung and Gajerrong from the building of those dams. It was hard for us to negotiate because some people were not going to get their land back, it had been flooded (p. 68). 
Jackson, S. and M. Barber 2016. Historical and contemporary waterscapes of North Australia: Indigenous attitudes to dams and water diversions. Water History 8(4): 385-404 http://hdl.handle.net/10072/204548

In 2000, government plans to expand the footprint of the irrigation area triggered formal negotiations with Indigenous owners. An Indigenous negotiating committee was formed that comprised all of groups who were 'connected by the water. Anyone affected by the water was invited to the committee' (Barber and Kennedy 2007, p.70). A negotiated settlement was reached in 2006 and terms of the agreement included extinguishment of native title over parts of the irrigation area, compensation for the original stage one development, land transfers (with water licenses) and an Indigenous development fund, as well as devolution of management responsibilities in some areas. Almost A $\$ 12$ million was provided over four years to leverage funds to address the historical grievances associated with the initial Ord scheme.

Indigenous evaluations of and reactions to the post-dam waterscape that are briefly described here contrast with a popular settler development ethos that sees dams and irrigation as hydrotechnologies that open up the northern frontier, bringing innovation and promise to a region previously unproductive (Jackson et al. 2008; Head 2000). The water that flowed in great volumes along the Ord to the sea every year was regarded as "wasted". That particular hydroimaginary continues to hold currency in development debates over the north and has shaped the water resource development discourse pertaining to our last case, the Gilbert River in North Queensland.

$\underline{\text { Responding to a future waterscape: damming the Gilbert River, Queensland }}$

The last case we present here is the Gilbert River in Queensland, a catchment that has recently been the subject of considerable speculation regarding its potential to support a large scale irrigation scheme ${ }^{1}$. The Gilbert contains archaeological evidence of an Indigenous waterscape stretching back many thousands of years. Observations by early explorers such as Ludwig Leichhardt (1846) described human occupation around lagoons and waterholes, and a later expedition by the Jardines noted that a 'great many fishing weirs were observed in the channels of the river, from which it would appear that the blacks live much, if not principally, on fish' (Byerley 1949, Sept 11 entry). Extrapolating from the colonial material and examples from elsewhere, Wegner describes a waterscape characterized by seasonal dependence on water resources with

\footnotetext{
${ }^{1}$ The information from this case study is drawn from consultations (Barber 2013) that were a component of a larger project undertaken by the Australian government research agency, the CSIRO, which examined the potential for water resource and irrigation development. The project was initiated by the Federal government in response to expectations for increased international food and fibre demand.
} 
Jackson, S. and M. Barber 2016. Historical and contemporary waterscapes of North Australia: Indigenous attitudes to dams and water diversions. Water History 8(4): 385-404 http://hdl.handle.net/10072/204548

' $\ldots$ the population spreading across the land and into the ranges in the wet season, and contracting back to the rivers in the dry. Once the rivers had stopped running, they would have further contracted to the permanent water-holes and lagoons and the springfed creeks' (1993, p.133).

Although the sources are fragmentary rather than systematic, the general picture suggests active habitation of the region by a substantial number of people who were using locally available and appropriate technologies to exploit aquatic and riparian resources.

Following the initial incursion by pastoralism, gold miners occupied the upper Gilbert catchment, especially impacting its waterways. By the mid-1880s, starvation, the threat of further violence, and inconsistent access to water forced the remaining Indigenous inhabitants of the region to settle on the fringes of the area's various towns. An Indigenous Reserve (a portion of Crown Land set aside for supervised Indigenous use) was considered but never established, substantially affecting Indigenous population levels in the upper Gilbert watershed thereafter. The pressures of colonial violence and forced relocations made the maintenance of traditional connections and ways of life difficult over subsequent generations. As a result, compared with the previous examples, the Indigenous people of the upper Gilbert River have had less opportunity to interact with their customary land and waterscapes. Relatively few Indigenous people currently live in the watershed, and places that were important residential sites in the past are now not permanently inhabited, and for a range of reasons, particularly accessibility, may rarely have been visited in recent decades (Barber 2013).

Nevertheless, locations that are not frequently visited may still be crucial in peoples' lives, sustaining a distinct individual and group identity as well as connections to past ancestors and future descendants. Native title claims in the upper part of the Gilbert catchments by the Ewamian and Tagalaka peoples have recently been determined and contain a range of use and access rights, including provisions for non-exclusive hunting and fishing rights and for the right to take and use the water for personal, domestic and non-commercial communal purposes. The major downstream group, the Kurtijar, is yet to have its claims for native title fully investigated, but the group owns a substantial and successful pastoral property, Delta Downs, that encompasses the lower Gilbert catchment. The fisheries of the adjacent Gulf are supported by the river flows, providing crucial sources of sustenance for the many coastal Indigenous groups living throughout the southeastern Gulf as well. 
Jackson, S. and M. Barber 2016. Historical and contemporary waterscapes of North Australia: Indigenous attitudes to dams and water diversions. Water History 8(4): 385-404 http://hdl.handle.net/10072/204548

The forces of colonization in the Gilbert catchment have driven where and how people lived, but historical memory and the stories of the elders about the past are nevertheless important in contemporary knowledge, identities and attitudes. Water is often a crucial focus for Dreaming narratives, and serpents are particularly associated with water places:

'When you look at Cobbold Gorge, that is where the Robertson River comes out, further down. The springwater comes out of the sandstone into the creek, then into the Gilbert River. It never dries. That water is never capped. The story goes that if the spring is there, there rainbow serpent keeps it flowing. You get rid of that flow, you have no serpent...Water has power, spiritual connection. The rivers are boundaries. The serpent sits under the spring water, sits there' Senior Ewamian person (cited in Barber 2013: $38)$.

For Indigenous people in the Gilbert, the strong patterns of seasonal change are seen as an important part of the natural cycle underpinning the local waterscape, and of the human health and wellbeing which relies on that cycle. The larger water flows of the wet season are viewed as particularly important:

'Water running down flushes everything out. The floods clean it out so you can drink it, give you that clean source of water. Sometimes, if the water is kept there for a long time and does not get a flush out, it is no good. Climate change, you might get a drought for 3-4 years, then the water is not good to drink and the wet season may not flush it out. The flood flow is important to the river system' Senior Ewamian person (cited in Barber 2013: 62).

To date, the development of water storage infrastructure has been relatively modest (Barber 2013). Small instream dams and weirs service townships, provide stock and domestic water and supply water for mining and small scale private irrigation. Significant land clearing was recently undertaken to prepare for larger scale water harvesting, but the Gilbert River currently remains relatively free-flowing. As was noted in the introduction, this situation may not last. A private consortium has proposed to build a large dam and water harvesting system in the upper Gilbert in order to supported irrigated agriculture and intends to take up a very substantial water license from the Queensland government (Schwartz 2015). 
Jackson, S. and M. Barber 2016. Historical and contemporary waterscapes of North Australia: Indigenous attitudes to dams and water diversions. Water History 8(4): 385-404 http://hdl.handle.net/10072/204548

In imagining dams and water diversions of the future, Indigenous people from the Gilbert catchment expressed concerns about an array of risks and impacts. These reflect knowledge of existing environmental features, concerns about environmental change, awareness of problems with similar developments elsewhere, concerns about cumulative impacts from other existing or proposed developments, and the vulnerabilities of their own communities and lifestyles to particular kinds of impacts. These concerns arise from a general sense of the value of the existing waterscape:

'When I look at the country I see my ancestors. That's why when I see irrigation, it is disturbing, because we also have that connection beneath the ground. As time goes on, that's where everything goes. It gets buried. It will affect all that, the country itself. The connection to the country is through the water, without that we don't have country. Without water - the rivers and waterholes, birthplaces and story places - we are nothing' Senior Ewamian person (cited in Barber 2013: 40).

They also are expressed in terms of valuing the potential for water development, but emphasizing the prioritization of particular kinds of water development technology over others:

'I'm not against farming, but I'm against damming the rivers to do it. They need to get that water some other way' Senior Tagalaka E (cited in Barber 2013: 89).

'My vision is that I'd like to see flood pumping happen. Pump out of the wet season flow into tanks that service what you grow there. It is better than bores. We don't know what the underground water is up to. If they do bores, it might take the water down and dry the springs out. The bores affect the spring water on the sandstone escarpment. Those springs have been there millions of years. But bores is better than a dam I think' Senior Ewamian person (cited in Barber 2015: 67).

The prioritization of particular kinds of water resource development technology arises out of a concern to respect past ancestry and present inhabitants, but also from a sense of responsibility to future generations. For Indigenous people along the Gilbert River, imagining a future waterscape that contains dams and diversions involves reflecting on the legacy of a pre-colonial and colonial past, on the need to respond to the challenges and opportunities of the present, and on the need to consider the custodians of waterscapes in a future well beyond the timeframes used by those who are formally tasked with the planning, design and construction of such 
Jackson, S. and M. Barber 2016. Historical and contemporary waterscapes of North Australia: Indigenous attitudes to dams and water diversions. Water History 8(4): 385-404 http://hdl.handle.net/10072/204548

infrastructure. Equity in the distributions of risks, benefits, and costs is crucial to Indigenous conceptions of viable futures.

\section{Discussion and conclusion: damming and diversion in north Australian Indigenous waterscapes}

The waterscape framework encourages the analysis of relationships between water and society within a particular socio-spatial context (Perreault et al. 2012). The cases presented here differ in location by thousands of kilometers, and encompass historical periods that range from the pre-colonial to beyond the present. Yet they all lie in north Australia, a region that is characterized by high variability in river flow, largely unregulated and relatively healthy river systems, and a similar progression in techno-ecological histories of human use of natural resources and associated environmental transformations. Autonomous Indigenous environmental management of this region, particularly fire-stick farming which entailed the intentional modification of the landscape through fire (Jones 1969), was frequently displaced by the needs of colonial pastoral and mining land-uses, followed in turn by attempts at agriculture that have consistently struggled to be realized at scale (Cook et al. 2012). Notwithstanding these environmental transformations, Indigenous communities have persistently sought to manage land and water in accordance with local norms, customs and values. Strongly identifying with water sources and these social institutions contributes significantly to identity formation in Indigenous societies. Using waterscapes as a common framing brings these consistencies more clearly into focus.

The dams and water diversions we review are also major regional and typological markers: the Roper dams are now the best documented instance of Indigenous water management in north Australia; the Harding is the highest profile historical water resource development in the most economically important mining region of Australia; the Ord scheme is the biggest and most controversial agricultural experiment; and the Gilbert River is the most recent and, if built, will rival the Ord in both scale and impact. Placing these examples side by side and viewing them through the lens of waterscapes highlights the distinct but relatable geographical and historical contexts that characterize these socio-spatial configurations.

In north Australia, dams have only been constructed in a relatively small number of cases, but for over a hundred years they have remained a symbol of white settler progress, underpinning 
Jackson, S. and M. Barber 2016. Historical and contemporary waterscapes of North Australia: Indigenous attitudes to dams and water diversions. Water History 8(4): 385-404 http://hdl.handle.net/10072/204548

the mythology of an idealized agricultural future for the north, periodically exciting the attention and enthusiasm of those for whom northern development is as much an emotional, cultural and political imperative as a pragmatic economic goal. These have included generations of private developers, of local, state and national politicians and of the bureaucrats who work with and for them. Images of nature have been as least as influential in driving the many inquiries, proposals and feasibility studies as have 'any rational or quantitative assessments' (Head 2000, p.175). One consequence of these cultural politics (Baviskar 2003) is that Indigenous rights, roles, and responsibilities in northern waterscapes have been marginalized in favour of the economic interests and environmental evaluations of the nonindigenous population. Water has been integral to the "establishment and consolidation of highly racialised social, political, and economic configurations' (Perreault et al. 2012, p.501) characteristic of settler colonial Australia: the northern pastoral industry, frontier mining booms, and export-oriented, irrigation schemes pursued in an attempt to civilize and domestic the unfamiliar and wild landscapes of the north and extract profits from its natural resources (Jackson et al. 2008; Powell 1991).

The colonial and settler colonial processes through which Aboriginal rights and interests were variously ignored, suppressed, occluded and/or dominated were often highly effective, and in many circumstances, recovering past traces is extremely difficult. Therefore, contexts in which both oral histories and detailed historical and legal records of past actions and encounters are found to exist are of great value (such as the upper Roper described here), as are the kinds of secondary accounts that we have drawn upon here from our other cases to understand the dynamic quality of waterscapes. With this kind of information we can more readily provide careful historical contextualisation which is, according to Bender, a prerequisite for understanding the 'contestations and appropriations of a landscape' (1993: 248). There are other reasons for undertaking historical analyses of waterscapes, one of which is particularly pertinent in settler societies. Some sectors of Australian society express reluctance to acknowledge the importance of the past, to learn more about the negative aspects of colonial events and processes and to engage with the important role of historiography. Denial of the political resonance of the past has the paradoxical effect of confirming its critical importance in understanding contemporary anxieties about Australian history. The claim that the past is behind us confirms the importance of understanding how it was that white settlers came to dominate and suppress Indigenous cultures - and in this context their water cultures - as well as the 
Jackson, S. and M. Barber 2016. Historical and contemporary waterscapes of North Australia: Indigenous attitudes to dams and water diversions. Water History 8(4): 385-404 http://hdl.handle.net/10072/204548

value of reflecting on the continuities and discontinuities with the structures of power illuminated by historical analysis.

Attention to the power relations at work in any given waterscape at any given historical moment reveals the relationship between social power and water access and, according to Swngedouw (2006), that relationship is most acute for agricultural systems that are dependent on hydraulic infrastructure and irrigation. In the Ord case we can see marked in the pattern of distribution the unequal power relations that were established under colonialism and never fully redressed in the native title settlement that excluded commercial water rights for Indigenous claimants from its terms (McLean 2012). With dams and hydraulic infrastructure, water access and use was massively improved for the non-Indigenous settler-farmer who was applying water to its highest use according to white settler norms, whereas it was made worse for the Indigenous owner groups whose water uses and cultures were rendered invisible by state infrastructure planning processes (Head 1999). Construction of two dams and lakes in the Ord valley altered the landscape and put lands flooded by those waters beyond the reach of the traditional owners. Although directed towards supporting the population of workers in the mining industry, the dynamics of the Harding Dam in the Pilbara were similar, as the radically changed the flows of water undermined water and associated food security for Indigenous people.

Water is also crucial to historical and current struggles by Indigenous peoples to negotiate the conditions under which they can maintain tradition and use of customary estates, benefit from emerging regional development activities and pursue management strategies that protect the valued relationships that are so critical to Indigenous identities and lifeways (Jackson \& Barber 2013; Bark et al. 2015; Maclean \& Bana Yarralji Bubu Inc. 2015; Nikolakis \& Grafton 2014). The case of the Roper River weirs thus shows another valuable aspect of waterscapes, bringing to light the role of Indigenous agency in directing water to deliberately create and recreate new waterscapes. Perhaps more than a large scale dam, these structures emphasize that water infrastructure is a product of human labour, and therefore, that water can embody and represent human action. The autonomy of the pre-colonial structures was altered by subsequent colonization, but not so much that this act of creation was suppressed. Indigenous people remained in control of a technology that they at times used despite, rather than because of, the intervention of settler colonial pastoral and riparian institutional structures.

The Indigenous dams and diversions that were a key feature of the Roper River waterscape provide a means of understanding responses to a future waterscape on the Gilbert River. Great 
Jackson, S. and M. Barber 2016. Historical and contemporary waterscapes of North Australia: Indigenous attitudes to dams and water diversions. Water History 8(4): 385-404 http://hdl.handle.net/10072/204548

concerns about the potential consequences of a large, industrial scale dam are expressed, but not to the degree that human intervention in water flows cannot be considered. Rather, what is emphasized is that the nature of such intervention must be appropriate, that it must consider the ancestral past and future generations, as well as those living downstream. Geographical and intergenerational equity considerations in the relative distribution of risk and opportunity is fundamental to Indigenous perspectives. The Indigenous waterscape of the Gilbert River is configured in both time and space, and considerations of how it might be altered through human intervention need to adopt a corresponding orientation.

The four case studies considered here highlight that Indigenous positions with respect to damming and diversion reflect the complexity of past engagements with water and the diversity of contemporary geographical and historical circumstances. Understanding these positions as a manifestation of a wider Indigenous waterscape enables strong links to be drawn between water and social power - Indigenous people are often concerned about the social, economic, and environmental impacts of industrial-scale water diversion and damming. Yet also evident in the material is that Indigenous cultures support and enable human alterations to hydrology, and that these hydraulic environments are themselves affected by past human action. It is a question of what human agency and human responsibility entails, and critically, a question of who bears the risk, costs and benefits, rather than whether any action is permissible.

Such perspectives can inform international debates about addressing water scarcity and water variability in regions occupied by Indigenous peoples, and about the large scale water-intensive developments that remain default choices in the search for solutions. The World Commission on Dams (WCD) concluded that construction of some 45,000 large dams had caused displacement and severe poverty for a conservatively estimated 40 to 80 million people, the majority of whom were Indigenous peoples and ethnic minorities (Johnston 2010; Fujikura \& Nakayama 2009). It is commonplace in contests over dam development to see the water cultures of Indigenous groups and ethnic minorities opposing river regulation and impoundment cast as backward, irrational and primitive, in contrast to the putatively superior technologies and rationalities empowered by modernist water management systems (Klaver 2012; Jackson \& Palmer 2012; Boelens \& Seeman 2014). Such a characterization both relies upon and augments the marginal political position and disadvantaged economic status of most Indigenous peoples, who as a consequence have relatively restricted access to productive water resources and are especially vulnerable to water injustices (Jackson 2016). 
The WCD responded to a transnational discourse of 'recognition' and the Indigenous movement's calls for self-determination and strong protection for Indigenous rights (Carino \& Colchester 2010). It did this by assuming a broad normative framework and recommending the application of a human rights and risks approach to negotiating with Indigenous stakeholders affected by dams. Recommendations included the requirement for free, prior and informed consent to development projects, a principle that is central to the United Nations Declaration on the Rights of Indigenous Peoples. This benchmark was built on the need to gain public acceptance of key decisions, to take account of local perspectives, rights and interests, minimize ecosystem impacts and create an entitlement for affected Indigenous groups to negotiate mutually agreed and legally enforceable mitigation, resettlement and development plans, with benefit-sharing provisions.

Such principles can only be enacted through transparent, legitimate and participatory processes which reveal local waterscapes - the group values, the significance of water and hydro-social relations to cultural identities, and the part that local systems of water governance play in creating and sustaining human place-based connections and livelihoods. Accounts generated by and with Indigenous peoples based on their own perspectives are therefore essential to the success of efforts. A more complete understanding of the cultural specificity of attitudes towards water resource development, and of the formative role of water histories in the generation of local water governance norms, values and the distribution of water access rights or entitlements will result. 
Jackson, S. and M. Barber 2016. Historical and contemporary waterscapes of North Australia: Indigenous attitudes to dams and water diversions. Water History 8(4): 385-404 http://hdl.handle.net/10072/204548

\section{References}

Abbott WE (1884) Water supply in interior NSW. Journal and proceedings of the Royal Society of New South Wales 18:85-111

Altman J, Kerins S (eds) (2012) People on Country: Vital Landscapes, Indigenous Futures. Federation Press, Sydney

Australian Tropical Rivers Group (2004) Securing the north: Australia's tropical rivers. A Statement by the Australian Tropical Rivers Group. World Wildlife Fund, Sydney

Bandler H (1995) Water resources exploitation in Australian prehistory environment. The Environmentalist 15:97-107

Barber K, Kennedy E (2007) Indigenous values and the Ord River. In Jackson S (ed) Recognising and protecting Indigenous values in water management: A report from a workshop held at CSIRO in Darwin, NT. CSIRO Sustainable Ecosystems, Darwin, pp $67-81$

Barber, K. \& Rumley, H., (2003) Gunanurang: (Kununurra) Big River Aboriginal Cultural Values of the Ord River, Report to the Water and Rivers Commission, Perth: Water and Rivers Commission of Western Australia

Barber M (2005) Where the clouds stand: Australian Aboriginal attachments to water, place, and the marine environment in Northeast Arnhem land. PhD Thesis, Australian National University

Barber M (2013) Indigenous water values, rights and interests in the Flinders and Gilbert catchments: A technical report to the Australian Government from the CSIRO Flinders and Gilbert Agricultural Resource Assessment. CSIRO, Brisbane

Barber M, Jackson S (2011a) Aboriginal water values and resource development pressures in the Pilbara region of north-west Australia. Australian Aboriginal Studies 2:32-49

Barber M, Jackson S (2011b) Indigenous water values and water planning in the Upper Roper River, Northern Territory. Unpublished Report. CSIRO, Darwin

Barber M, Jackson S (2012) Indigenous engagement in Australian mine water management: The alignment of corporate strategies with national water reform objectives. Resources Policy 37:48-58

Barber M, Jackson S (2014) Autonomy and the intercultural: interpreting the history of Australian Aboriginal water management in the Roper River catchment, Northern Territory. Journal of the Royal Anthropological Institute 20:670-693

Barber M, Jackson S (2015) Remembering “the blackfellows" dam': Australian Aboriginal water management and settler colonial riparian law in the upper Roper River, Northern Territory. Settler Colonial Studies 5: 282-301

Bark RH et al. (2015) Operationalising the ecosystem services approach in water planning: A case study of indigenous cultural values from the Murray-Darling Basin, Australia. International Journal of Biodiversity Science, Ecosystem Services \& Management 11:239-249 
Jackson, S. and M. Barber 2016. Historical and contemporary waterscapes of North Australia: Indigenous attitudes to dams and water diversions. Water History 8(4): 385-404 http://hdl.handle.net/10072/204548

Baviskar A (2003) For a Cultural Politics of Natural Resources. Economic and Political Weekly 38:5051-5055

Blanch S (2008) Steps to a sustainable northern Australia. Australian Journal of Ecological Management and Restoration 9:110-115

Boelens R (2013) Cultural politics and hydrosocial cycle. Geoforum 57:234-247

Boelens R, Seeman M (2014) Forced engagements: Water security and local rights formalization in Yanque, Colca Valley, Peru. Human Organization 73:1-12

Bradley J (2010) Singing Saltwater Country: Journey to the songlines of Carpentaria. Allen \& Unwin, Melbourne

Brennan S. et al. (eds) (2015) Native Title from Mabo to Akiba: A Vehicle for Change and Empowerment? Federation Press, Sydney

Budds J (2008) Whose scarcity? The hydrosocial cycle and the changing waterscape of La Ligua River Basin, Chile. In Goodman, M. K. (ed) Contentious geographies, environmental knowledge and meaning. Ashgate, Surrey, pp 59-68

Budds J, Hinojosa L (2012) Restructuring and rescaling water governance in mining contexts: The co-production of waterscapes in Peru. Water Alternatives 5:119-137

Byerley F (ed) 1949 Narrative of the overland expedition of the messrs Jardine, from Rockhampton to Cape York, Northern Queensland. Angus and Robertson, Brisbane

Carino J, Colchester M (2010) From dams to development justice: Progress with "free, prior and informed consent" since the World Commission on Dams. Water Alternatives $3: 423-437$

Cook GD, Jackson S, Williams RJ (2012) A revolution in northern Australian fire management: Recognition of Indigenous knowledge, practice and management. In Bradstock R, Gill A, Williams R (Eds) Flammable Australia: Fire regimes, biodiversity and ecosystems in a changing world. CSIRO, Melbourne pp 293-305

Cooper D, Jackson S (2008) Preliminary study on Indigenous water values and interests in the Katherine region of the Northern Territory. CSIRO, Darwin

Daniel D (1990) Thalu sites of the West Pilbara.Unpublished Report, Western Australian Museum, Perth.

Davidson G (1972) The Northern Myth: Limits to agricultural and pastoral development in tropical Australia. Melbourne University Press, Melbourne

Fujikura R, Nakayama N (2009) Lessons learned from the World Commission on Dams. International Environmental Agreements: Politics, Law and Economics 9:173-190

Gammage B (2011) The Biggest Estate on Earth: How Aborigines Made Australia. Allen \& Unwin, Sydney.

Gosford B (2014) Good money after bad. The NT Government and the Ord River Irrigation Scheme, Crikey.com

Gunn J (1908) We of the Never-Never. Project Gutenberg: EBook \#4699 Project Gutenberg.

Head L (1999) The Northern Myth Revisited? Aborigines, environment and agriculture in the 
Jackson, S. and M. Barber 2016. Historical and contemporary waterscapes of North Australia: Indigenous attitudes to dams and water diversions. Water History 8(4): 385-404 http://hdl.handle.net/10072/204548

Ord River Irrigation Scheme, Stages One and Two. Australian Geographer 30:141-158

Head L (2000) Second Nature: The History and Implications of Australia as Aboriginal Landscape. Syracuse University Press, New York

Humphries P (2007) Historical Indigenous use of aquatic resources in Australia's MurrayDarling Basin, and its implications for river management. Ecological Management \& Restoration 8:106-113

Hundley N (1987) California's original waterscape: Harmony and manipulation. California History 66:2-11

Jackson S (2016) Indigenous peoples and water justice in a globalizing world. In Conca K, Weinthal E (eds). Oxford Handbook on Water Politics and Policy. Oxford University Press, Oxford

Jackson S et al. (2008) The Changing Value of Australian Tropical Rivers. Geographical Research 46:275-290

Jackson S, Altman, J (2009) Indigenous rights and water policy: Perspectives from tropical northern Australia. Australian Indigenous Law Review 13: 27-48

Jackson S, Barber M (2013) Recognition of indigenous water values in Australia's Northern Territory: Current progress and ongoing challenges for social justice in water planning. Planning Theory \& Practice 14: 435-454

Jackson S, Palmer L (2012) Modernising water: articulating custom in water governance in Australia and Timor Leste. International Indigenous Policy Journal, 3(3). Available at: Retrieved from: http://ir.lib.uwo.ca/iipj/vol3/iss3/7

Johnston BR (2010) Chixoy dam legacies: The struggle to secure reparation and the right to remedy in Guatemala. Water Alternatives 3:341-361

Jones, R (1969) Fire stick farming. Australian Natural History 16:224-231

Klaver IJ (2012) Placing water and culture. In Johnston BR (ed) Water, Cultural Diversity, and Global Environmental Change. Springer Dordrecht, Heidelberg, pp. 9-30

Langton M (2002) Freshwater. In Background Briefing Papers: Aboriginal Rights to Waters. Broome. Lingiari Foundation, Western Australia, pp. 43-64

Langton M, Mazel O (2008) Poverty in the midst of plenty: Aboriginal people, the 'resource curse' and Australia's mining boom. Journal of Energy and Natural Resources Law 26:31-65.

Leichhardt L (1846) Journal of an overland expedition in Australia: from Moreton Bay to Port Essington, a distance of upwards of 3000 miles, during the years 1844-1845. 2004th ed. $\mathrm{T}$ and $\mathrm{W}$ Boone and Project Gutenberg, London

Loftus A (2007) Working the socio-natural relations of the urban waterscape in South Africa. International Journal of Urban and Regional Research 31:41-59.

Loftus A, Lumsden F (2008) Reworking hegemony in the urban waterscape. Transactions of the Institute of British Geographers 33:109-126

Lourandos H (1980) Change or stability?: Hydraulics, hunter-gatherers and population in temperate Australia. World Archaeology 11:245-264 
Jackson, S. and M. Barber 2016. Historical and contemporary waterscapes of North Australia: Indigenous attitudes to dams and water diversions. Water History 8(4): 385-404 http://hdl.handle.net/10072/204548

Maclean K, Bana Yarralji Bubu Inc. (2015) Crossing cultural boundaries:Integrating Indigenous water knowledge into water governance through co-research in the Queensland Wet Tropics. Geoforum 59:142-152

McGrath A (1987) Born in the Cattle. llen \& Unwin, Sydney

McLean J (2012) From dispossession to compensation: A political ecology of the Ord Final Agreement as a partial success story for Indigenous traditional owners. Australian Geographer 43:339-355.

Merlan F (1987) Catfish and alligator: Totemic songs of the western Roper River, Northern Territory. In M. Clunies-Ross, T. Donaldson, \& S. Wild, eds. Songs of Aboriginal Australia. Oceania Monograph 32:142-167

Nikolakis W, Grafton R (2014) Fairness and justice in Indigenous water allocations: insights from Northern Australia. Water Policy 16:19-35

Olive N (2007) Enough is Enough: a History of the Pilbara Mob. Western Australia: Fremantle Arts Centre Press, Fremantle

Orlove B, Caton S (2010) Water sustainability: Anthropological approaches and prospects. Annual Review of Anthropologylogy 39:401-415

Palmer K (1977) Aboriginal sites and the Fortescue River, north west of Western Australia'. Archaeology and Physical Anthropology in Oceania 12:4-8

Palmer K, Maynard L, Wright, B (1978) West Pilbara water supply investigations Aboriginal Sites. Report of survey for Aboriginal sites for the Public Works Department, WA. Perth

Palmer L (2015) Water Politics and Spiritual Ecology: Custom, environmental governance and development. Routledge, Oxford

Perreault T, Wraight S, Perreault M (2012) Environmental injustice in the Onondaga lake waterscape, New York State, USA. Water Alternatives 5:485-506

Powell J (1991) Plains of Promise Rivers of Destiny: Water Management and the Development of Queensland, 1824- 1990. Boolarong Publications, Brisbane

Rijavec F (1993) Exile and the Kingdom. Screen Australia, Sydney.

Rose DB (1996) Nourishing terrains: Australian Aboriginal views of landscape and wilderness. Australian Heritage Commission, Canberra

Rumley H, Barber K (2004) "We Used to Get our Water Free..." Identification and Protection of Aboriginal Cultural Values of the Pilbara Region, Report for the Westen Australian Water Supply Commission, Perth

Schwartz D (2015) Queensland Government reportedly strikes deal to facilitate \$2 billion IFED irrigated agriculture project. Available at: http://www.abc.net.au/news/2015-0604/qld-government-strikes-deal-to-facilitate-ifed-project/6520090.

Stoeck1 N et al. (2013) An integrated assessment of financial, hydrological, ecological and social impacts of "development" on Indigenous and non-Indigenous people in northern Australia. Biological Conservation 159:214-221

Swyngedouw E (1999) Modernity and hybridity: Nature, regeneracionismo, and the 
Jackson, S. and M. Barber 2016. Historical and contemporary waterscapes of North Australia: Indigenous attitudes to dams and water diversions. Water History 8(4): 385-404 http://hdl.handle.net/10072/204548

production of the Spanish waterscape, 1890-1930. Annals of the Association of American Geographers 89:443-465

Swyngedouw E (2004) Social power and the urbanization of water: Flows of power. Oxford University Press, Oxford

Toussaint S, Sullivan P, Yu, S (2005) Water ways in in Aboriginal Australia: an interconnected analysis. Anthropological Forum: A Journal of Social Anthropology and Comparative Sociology 15:61-74

Webster T et al. (2009) Irrigated agriculture: development opportunities and implications for northern Australia. In Stone, P (ed) Northern Australia Land and Water Science Review, Final Report to the Northern Australia Land and Water Taskforce. CSIRO Publishing, Canberra

Wegner J (1993) Aborigines of the Etheridge shire, 1860-1940. In Reynolds H. (ed) Race relations in North Queensland. James Cok University, Townsville, pp 131-147

Williams N (1986) The Yolngu and their land: A system of land tenure and the fight for its recognition. Australian Institute Of Aboriginal Studies, Canberra

World Commission on Dams (2000) Dams and development: A new framework for decisionmaking. The Report of the World Commission on Dams. Earthscan, London. 
Jackson, S. and M. Barber 2016. Historical and contemporary waterscapes of North Australia: Indigenous attitudes to dams and water diversions. Water History 8(4): 385-404 http://hdl.handle.net/10072/204548

Figure 1 Map of north Australia showing case studies 